\title{
Література:
}

1. Великий тлумачний словник сучасної української мови / уклад. І гол. ред. В.Т. Бусел. К.: Ірпінь: ВТФ «Перун», 2005. 1728 с.

2. Жуков В.П. Технологія підготовки майбутніх учителів музичного мистецтва до інтегрованого навчання учнів. Вісник Національного університету "Чернігівський колегіум» імені Т. Г. Шевченка. Серія: Педагогічні науки. 2019. № 1. С. 44-48.

3. Масол Л.М. Методика навчання мистецтва у початковій школі: посіб. для вчителів / Л.М. Масол, О.В. Гайдамака, Е.В. Бєлкіна, О.В. Калініченко, І.В. Руденко. Х.: Веста ; Видавництво «Ранок», 2006. $256 \mathrm{c}$.

4. Масол Л.М. Художньо-педагогічні технології в основній школі: єдність навчання i виховання: метод. посіб. Харків: «Друкарня Мадрид», 2015. 178 с.

DOI https://doi.org/10.30525/978-9934-26-041-4-73

\section{COMPETENCE-BASED APPROACH TO THE DEVELOPMENT OF INFORMATION AND ANALYTICAL COMPETENCE OF HIGHER EDUCATION APPLICANTS IN THE PROCESS OF FOREIGN LANGUAGE TRAINING}

\author{
Karasova L. A. \\ Candidate of Pedagogic Sciences, \\ Associate Professor at the Department of Romanic and Germanic \\ Languages \\ National Academy of the Security Service of Ukraine \\ Kryvych M. L. \\ Candidate of Pedagogic Sciences, Associate Professor, \\ Director of the Language Training and Scientific Center \\ National Academy of the Security Service of Ukraine \\ Latysheva N. Ye. \\ Candidate of Philological Sciences, Associate Professor, \\ Professor at the Department of Romanic and Germanic Languages \\ National Academy of the Security Service of Ukraine \\ Kyiv, Ukraine
}

Nowadays, the learning of foreign languages is one of the important areas of training future specialists in departmental institutions of higher 
education. This type of education allows higher education students to form the necessary competences, develop personal and professionally significant qualities, and master a foreign language, given the specifics of their future professional activity. The focus of higher education on the development of students' professional competences makes it possible to nourish them as qualified professionals who not only have sound knowledge in their field but also are also able and willing to independently, consciously determine and adequately assess and adjust their own lives. Highly skilled specialists are intent on self-improvement, have well-developed critical thinking and skills to work in a team; are able to act confidently in non-standard life and professional situations, work with different sources of information; are armed with communication techniques.

It should be noted that in modern pedagogical science, the problem of competence is represented in a wide range of academic research, but there are still many of its discussion elements. Scholars in Ukraine and abroad believe that the system of competences in education has a hierarchical structure, the levels of which are: key, general and subject competences. Most scholars speak about the need to select and thoroughly identify a limited set of key competences that are most important and integrated $[1 ; 2 ; 3]$.

According to the results of the report of the expert groups, the following categories of key competences are - personal, social and learning competence; literacy competence; science, technological, engineering and mathematical competence; civic competence; cultural awareness and expression competence; entrepreneurship competence; language competence and digital competence. The acquisition of key competences can give a person the opportunity to keep their eye on the big picture, be well-informed about current situation, be familiar with information environment, and get further education. Experts who proposed such a set noted that learning languages remains one of the key competences for lifelong learning [4; 5, p.38].

It can be argued that a common system of hierarchy of competences of the individual does not exist currently. However, it is easy to see the unanimity in the opinion of scholars that because of education key competences become the basis for the person's readiness to effectively organize internal and external resources to achieve a target goal. Thus, by competence we mean a personal characteristic that contains knowledge, skills, abilities and attitudes that allow a future specialist to act effectively in a particular professional activity.

An integral part of the professional competence of future law enforcement officers is foreign language sustainment and enhancement, preparation of analytical reports based on foreign sources, ability to analyze foreign authentic scientific studies in the field of law enforcement with the 
aim of using their results in specific professional situations. The following types of professional activities of the graduates of departmental higher education institutions are: information and analytical work with various sources of socio-economic, military-political, legal and other professionally significant information; professional engagement in the course of making contact with native speakers of the target language; independent work on improving the level of a foreign language proficiency. Each of these types of professional activity contains a subtask type the relevance of which is determined by specialists. Types of speech activity and language skills are specified in academic course working programs - «Foreign Language», «Foreign Language for Special Purposes». These programs include the main types of speech activity: reading, speaking, listening, writing, and special types of speech activity: translation, summarizing and annotation.

Analysis of above-mentioned programs has led us to conclusion that a foreign language has a high cultural potential and can be successfully used as a means of forming analytical and information competence of future specialists. The concept of «information and analytical competence» as a scientific and pedagogical category has become especially relevant in connection with the formation of a modern information society. Depending on the characteristics of the professional activity of specialists of varied employment, preference is given to information or analytical competence. Two-parameter structure of information and analytical competence is its main and important property. There is a relationship between information and analytical competences, as elements of analytical competence appear to form part of information competence, and are reflected in the ability to analyze information. Scientific sources analysis allows us to point out that information and analytical competence of future specialists by definition of scholars is a component of professional competence, which reflects the readiness and ability of students to apply information and analytical skills in combination with their personal qualities while processing information of different types and forms of presentation $[6 ; 7 ; 8 ; 9]$. It is also important for a future specialist to be able to search, evaluate, store, analyze, formulate and disseminate sensitive information in order to obtain qualitatively new knowledge for making the right decision in professional activity.

Therefore, it can be concluded that the research and teaching staff of departmental higher education institutions challenge problem of great importance. They have to find the most modern and effective teaching methods and technologies that will help organize the educational process on a competence-based approach and will most effectively promote professionally oriented foreign language competence, professionally 
significant qualities and professional becoming of future specialists by means of a foreign language.

\section{References:}

1. Бутенко В. Г. Роль вищої технічної освіти у формуванні громадянських цінностей майбутніх фахівців. Педагогічна наука: історія, теорія, практика, тендениії розвитку. 2010. № 2. С. 35-38.

2. Савченко О. В. Компетентність особистості на когнітивному piвні. Проблеми сучасної психології. Вип. 25. С. 413-427. URL: http://nbuv.gov.ua/UJRN/Pspl_2014_25_35 (дата звернення 14.02.2021).

3. Федорук Г. М. Формування інформаційно-комунікаційної компетентності майбутніх вчителів технологій у процесі професійної підготовки6 ди с. ... канд. пед. наук. 13.00.04.Вінниця, 2015. С. 28-29.

4. Овчарук О. В. Особливості запровадження компетентнісного підходу: досвід України та країн Свропи. Інформаційні технологї в освіті: зб. наук. праць. Херсон, 2009. № . 4. С. 218-225.

5. European Commission. Proposal for a Council Recommendation on Key Competences for Lifelong Learning. (COM(2018).24 final). URL: https://eur-lex.europa.eu/legal-content/EN/TXT/PDF/?uri= CELEX:52018SC0014\&from=EN (дата зверенення 18.02.2021).

6. Гайдамак Е. С. Информационно-аналитическая деятельность специалиста в области образования. Вестник Омского государственного ун-та. 2006. URL: https://www.studmed.ru/view/ gaydamak-es-informacionno-analiticheskaya-deyatelnost-specialista-voblasti-obrazovaniya_ac8277d707d.html (дата звернення 14.02.2021).

7. Елканова Т. М. Формирование информационно-аналитической компетентности в структуре общегуманитарного базиса образования. Высшее образование сегодня. 2009. № 12. С. 53-57.

8. Лобач Н. В. Формування інформаційно-аналітичної компетентності майбутніх лікарів в освітньому середовищі вищого медичного навчального закладу: автореф. ди с. ... канд. пед. наук: 13.00.04. Полтава, 2016. $21 \mathrm{c}$.

9. Ягупов В. В. Інформаційно-аналітична компетентність керівників ПТНЗ як основа моніторингу розвитку системи професійнотехнічної освіти. Моніторинг розвитку професійно-технічної освіти: метод. реком. / за ред. Т. В. Волкової. С. 38-51. URL: https://lib.iitta.gov.ua/8034/1/MONITIRONG_PTO.pdf (дата звернення 14.02.2021). 